\title{
Social Dimensions of Evolutionary Research: Discovering Native American History in Colonial Southeastern U.S.
}

\author{
Christopher M. Stojanowski
}

Published online: 4 May 2011

(C) Springer Science+Business Media, LLC 2011

\begin{abstract}
Beginning in the late sixteenth century, a series of Spanish missions was built in coastal Georgia and northern Florida. These missions were designed to convert and "civilize" the indigenous peoples of the region and establish a Spanish presence in the southeastern United States. The colony was not a success, and the missions were destroyed by the English by 1706 . The native population fared poorly and suffered massive loss of people due to epidemics and colonial period hardships. In this paper, I discuss microevolutionary analyses of archeological skeletal samples representing the native populations from the region. Analyses document changing patterns of variation and intergroup biological integration through time. Formal evolutionary interpretations are offered, but these are reinterpreted with respect to the social and historical context of the time period. Specifically, patterns of variation suggest a nascent Catholic Indian identity was emergent in Spanish Florida when the missions were destroyed. While this may indicate an evolutionary and historical "dead end" for the indigenous peoples of Florida, further interpretation of the data with respect to the later history of the early Seminole people suggests a continuous biological history can be inferred, linking Spanish period (seventeenth century) and Seminole period (eighteenth century) peoples of Florida within a unified historical narrative. This complex, ephemeral history has repercussions for interpreting evolutionary genetic data within a strict cladistic framework. In addition, this research contributes a human-
\end{abstract}

Grant Sponsor Wenner-Gren Foundation for Anthropological Research GR-7747

C. M. Stojanowski $(\bowtie)$

School of Human Evolution and Social Change,

Arizona State University,

Tempe, AZ 85287, USA

e-mail: Christopher.stojanowski@asu.edu istic component to the evolutionary sciences with respect to cultural patrimony and oral traditions, in this case, of the Seminole peoples.

Keywords Florida mission · Microevolution · Seminole . Ethnogenesis

Although humans have lost their position as the only animals capable of inter-generational transmission of behavior, researchers continue to probe the relevance of our social learning and culture-bearing history for understanding the pattern and process of human evolution. Studies of "gene-culture coevolution" began in earnest with classic anthropological work on the sickle-form hemoglobin variant's relationship to agriculture as well as how dairying conditioned the evolution of lactose tolerance. Advances in genomic technology now inform a number of similar studies linking natural selection to human phenotypes within a specific cultural milieu (Boyd and Richerson 1985; Durham 1991; Laland et al. 2010; Richerson and Boyd 2005; Richerson et al. 2010; Varki et al. 2008). This varied research focuses on behavioral (cooperation, altruism) and dietary (lactose tolerance) biocultural adaptations, as well as more monolithic and somewhat reified cultural traits such as language and intelligence. Most of this research proceeds under a top-down approach wherein individuals as agents of action and change are minimized, and culture is conceived as a set of behaviors or traits whose pattern of expression can be described in terms of frequencies, presence, and absence. Selection, and to a lesser extent drift, can then be used to describe the patterning of expression (Sabeti et al. 2006, 2007; Nielsen et al. 2007; Rendell et al. 2011). Gene-culture coevolutionary studies ascribe importance to human cultural adaptations as endogenous agents of environment transformation, with down-theline effects in the genome. This ever-expanding literature 
produces general knowledge and is not particularistic ethnographically or historically contextualized.

The "culture" in gene-culture coevolution is defined as "information... affecting individuals' behavior" (Laland et al. 2010) that is learned. While general enough, in practice, researchers are often analyzing overt behavior, that is, what people do and how those actions affect the evolution of the species - growing yams, dairying, imitating peers, non-kinbased cooperation. Less emphasis is placed on culture as a set of beliefs, feelings and tendencies, including the nuanced and complex topic of social identities. The distinction is subtle but relates to the differences between behavior (growing yams) and experience (yam surplus allows communal feasting), and part of experience at the individual level is his/her social relationships with others. This ultimately is what gives our lives meaning. Ethnic groups as cooperative (Boyd and Richerson 1987; MacElreath et al. 2003) or fitness maximizing (Salter 2001, 2004; van den Berghe 1981) adaptations have received some attention in the literature, but the role of evolutionary mechanisms, in particular patterns of mate exchange and gene flow, in reconstructing social identities has not been emphasized. Such research is, admittedly, historically particularistic, which makes broad generalization (model building) difficult beyond top-down statements about why humans coalesce into non-kin-based identity categories at all. Nonetheless, divorcing research on ethnic identities from the social experience of those participating in the process of "being ethnic" ignores the humanistic elements of human social experience, ironically a key element of what makes human uniqueness so interesting.

In this paper, I present an extended case study of ethnic identity transformation (ethnogenesis) that highlights the utility of evolutionary research for exploring and uncovering past social transformations that historical texts, the archeological record, and the genes of descendant communities may not record. This bottom-up approach turns the gene-culture coevolutionary framework on its head. Rather than culture being a force of environmental modulation that brings about genomic modification due to Darwinian selection, culture (here, social identity) is transformed through quotidian behaviors that have aggregate effects at the group level. This non-Darwinian, evolutionary process explicitly links mate exchange and resulting gene flow to the sharing of traditions and life course expectations among those participating in the process; social transformation is the result.

For the last decade, my research has focused on reconstructing evolutionary processes in colonial period mission populations in Florida and Georgia (Stojanowski 2001, 2003a, b, 2004, 2005a, b, c, d, 2009, 2010). This region (La Florida) was under Spanish control from circa 1565 until the first decade of the eighteenth century, and the native communities resident in the region were missionized by Franciscans for much of this time period (Gannon 1983; Geiger 1937; Lanning 1935; Worth 2001). Here, I summarize research on human skeletal remains from these missions, which emphasizes a critical but not often appreciated aspect of evolutionary research, the ability to reconstruct human behavior within the realm of reproduction (mate exchange or marriage). Evolutionary analyses of archeological human skeletal remains reflect actual, on-theground behavior that has not been filtered through the lens of historical chroniclers or subjected to the motivations of peoples' social and political identities. People's behavior may differ considerably from their recollection of that behavior (what people do versus what they say they do). But as they say, genes do not lie. And phenotypes, the physical expression of those genes, are permanent records of human reproductive interaction. Because the parentchild bond is so strong in most primates (itself Darwinian), the act of mate choice, though filtered through a distinctly human social lens, feeds back on those social filters to transform them. Therefore, decisions about mating partners during a time of intense sociopolitical transformation (postcolonial New World) would have tremendous relevance to the peoples living in those times. It is in this sense that my work also informs discussions of gene-culture coevolution.

In this paper, I develop a framework related to ethnogenesis - the historical and social development (not evolution) of a "people" (Hill 1996). I specifically discuss the implications of my research on seventeenth century Spanish mission populations for understanding eighteenth century Seminole ethnogenesis as the outcome of decades of sociopolitical change with both endogenous cultural components and exogenous processes specific to the colonial environment. In so doing, I hope this paper adds a humanistic component to the evolutionary sciences, here couched within historical and oral traditions and notions of cultural patrimony.

\section{A Brief History of Spanish Colonial La Florida}

Spanish missions of Florida and Georgia were some of the earliest in North America and reflect Spain's attempt to convert, civilize, and tax the indigenous populations of the New World while expanding the footprint of their empire. La Florida (named by Juan Ponce de Leon) was an outgrowth of Spanish interests in Mexico and the Caribbean (Lyon 1990; Thomas 1990; Worth 2001). The colony was established to thwart French Protestant colonization efforts in the lower Atlantic and to protect shipping lanes for the transfer of precious metals and other commodities back to Europe (Bennett 2001; Lyon 1990; Milanich 1999). Mission construction began along the coast of northern 
Florida (around St. Augustine) and southern Georgia during the late sixteenth century, expanded westward from St. Augustine through upper-central Florida, and eventually targeted the panhandle (Tallahassee) by 1633 (Fig. 1). Missionary activity peaked by 1650 (McEwan 2001; Oré 1936; Spellman 1965) when increasing conflict with the English led to several decades of building tensions and frontier conflicts that would eventually lead to the destruction of the missions during the first decade of the eighteenth century (Boyd et al. 1951; Milanich 1999; Worth 1995, 1998). After this, Spanish control was restricted to St. Augustine and its immediate environs, which served the needs of several hundred Catholic Indians.

An enumeration of several hundred is indeed a very small number. Precontact estimates of population size and density are variable but certainly number in the tens of thousands (Dobyns 1966, 1983, 1991; Hann 1986, 1987, 1988, 1990, 1996a; Worth 1998). These thousands of individuals lived along the coast of Georgia (Guale province-Jones 1978, 1980; Saunders 2000; Worth 2004) and northern Florida (eastern Timucua provincesDeagan 1978), throughout north-central Florida (western Timucua provinces-Milanich 1996, 2004), and the eastern panhandle (Apalachee province-Hann 1988; McEwan 2000). There were dozens of chiefdoms present throughout this region during the protohistoric period (Fig. 1). Language diversity was high, with Apalachee and Guale languages spoken in their respective provinces and more than a dozen different dialects spoken throughout the eastern and western Timucua provinces (Hann 1996a; Milanich 1996, 2004). Prehistorically, these different tribes or chiefdoms or language communities exhibited a number of differences, including settlement density, political structure, material culture, diet, and burial practices. It is important to recognize this diversity; it provides a baseline expectation of the relevant demographic and genetic landscape when European contact occurred.

\section{The Evolutionary Effects of European Colonization}

Social and demographic changes during the mission period define a number of parameters relevant to microevolutionary analysis. The most obvious is population size decline, which reflects the cumulative effects of epidemic disease, slave raiding, forced labor tribute, frontier conflict casualties, and the often overlooked factor of fugitivism. While many surely died unnatural deaths while living in mission communities, countless more simply left the Spanish sphere of influence and effectively disappeared from history (Hann
Fig. 1 Map of Florida and Georgia showing the names of the major chiefdoms and tribes present in the region during the seventeenth century. Labels in all caps are the three administrative provinces commonly identified in the literature (Apalachee, Guale, Timucua). Other names are the smaller chiefdoms that were part of the Timucua province, with the exception of Yamassee, Apalachicola, and Chacato, which were their own entities

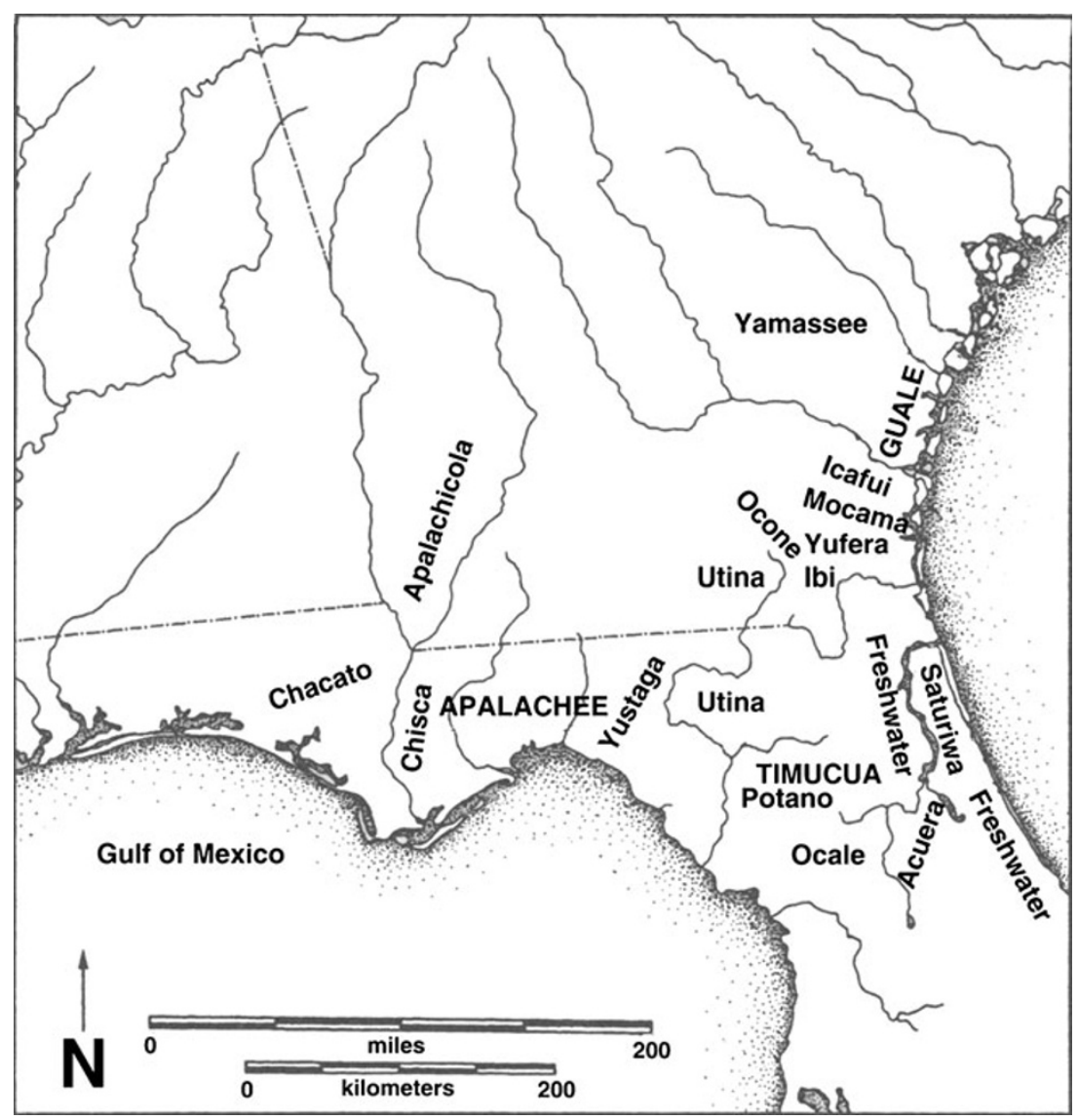


1996b; Worth 2006, 1998). The loss of people at the local and regional levels initiated counter-balancing processes, also with evolutionary impact. Population aggregation at mission centers increased initially by design (the goal was a settled civil workforce-Bushnell 1990; McEwan 2001) and eventually by necessity as entire villages disappeared and basic mechanisms of social function ceased. Likely, cultural proscriptions previously defining preferred marriage partners had to be modified. This was particularly so in a social and political context in which physical appearance reified social distinctions. The Spanish treated all natives as "Indians" regardless of language, heritage, or how Native Americans themselves viewed their relationships with other indigenous populations (see Bushnell 1990). This process of ascribing social identities based on appearance is inextricably linked to power differentials which effectively create racial divisions.

In addition to these social and demographic factors, population movements, sometimes over vast distances, also created new opportunities for mate exchange that may never have existed in prehistory. As disease spread into the frontier interior of North America (Kelton 2002, 2007), massive population dislocations occurred (Ethrdige 2006; Ethridge and Shuck-Hall 2009). As one example, the Florida missions were harassed by slave-raiding peoples whose origins lie in the Great Lakes region (Bowne 2005). Such displacements provided opportunities for mate exchange among formerly distant indigenous populations. Finally, European colonists took indigenous wives or consorts because of specific regulations curtailing the travel of women to the New World (Boxer 1975; Deagan 1973; McEwan 1991). African slaves provided another source of mates for indigenous peoples, which further increased the diversity of mate exchange partners for native populations (Landers 1997). In combination, then, population size decline suggests decreasing variability due to genetic drift while reactionary processes such as long-range migration and expansive systems of mate exchange suggest increasing variability due to gene flow.

\section{Biodistance Analysis and Microevolution in La Florida}

Excavations at several mission churches during the 1980s and 1990s produced a large number of human skeletal remains that could be combined with existing precontact period data to explore the effects of contact on native populations (see Jones and Shapiro 1990; Larsen 2001; Larsen et al. 2001; McEwan 1993; Thomas 1990). I chose to collect data on tooth size as a phenotypic proxy for genetic variability because tooth size is highly heritable and teeth preserve well in the archeological record, thus increasing sample size (Kieser 1990; Stojanowski 2010). I collected approximately 16 different measurements from each individual and sampled individuals from the three major language provinces in La Florida (Apalachee, Guale, Timucua) for each of three time periods: late prehistoric, early mission period (1600-1650), and late mission period (1650-1700) (Stojanowski 2001). The temporal divisions represent: (1) virgin soil populations (late prehistoric), (2) populations soon after converting to Catholicism living during the time of the greatest rate of demographic collapse (early mission period), and (3) populations living after demographic collapse during a phase of increased frontier hostility that would eventually lead to the missions' destruction late mission period. This sampling strategy allowed me to evaluate how variability changed within each province through time as well as how genetic relationships among different language groups changed through time.

To consider the evolutionary effects of missionization on native populations, I used several microevolutionary analyses which directly link statistical results to genetic characteristics of populations in a way that allows rigorous hypothesis testing (see Relethford 2003; Relethford et al. 1997). For example, we can now formally test whether variation within a population changed through time and link the direction of change (increasing variation or decreasing variation) to specific evolutionary mechanisms. In addition, patterns of variation between populations (Apalachee, Guale, and Timucua) can also be evaluated using parameters such as $F_{\mathrm{ST}}$ a metric which represents the distance between each population based on genetic or dental data and the hypothetical average of those populations (Fig. 2). A smaller $F_{\mathrm{ST}}$ value means the populations included in an analysis are fairly similar to each other, likely due to more extensive gene flow among large populations. A larger $F_{\mathrm{ST}}$ value suggests the populations are more divergent from each other, which could reflect the effects of genetic drift or less gene flow among the populations. These powerful approaches allow one to test whether parameters estimated using archeological data are statistically different from 0 , and whether the parameter values significantly changed through time, thereby inferring dynamics of population size and mate exchange in a temporal scale. By considering how variation changed within a population through time, as well as how variation between populations changed through time, we can infer which evolutionary mechanisms were affecting the populations under study.

Major findings of the application of these analyses to Florida mission data can be summarized as follows:

1. Populations living in La Florida during the late prehistoric period were relatively genetically integrated (Stojanowski 2005c, 2010). This is somewhat surprising given the level of political, cultural, and linguistic 


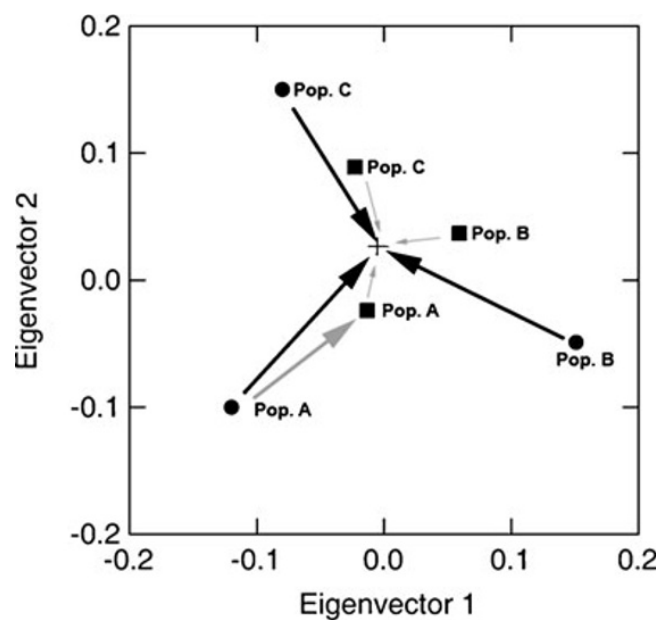

Fig. 2 Hypothetical plot showing the position of three populations ( $A$, $B$, and $C$ ) at two points in time (circles earlier, squares later). The plus sign is the average value for all populations for the variables used in this analysis. Arrows indicate how $F_{\mathrm{ST}}$ is calculated; it is the average value of each population from the overall mean of those populations (large black arrows). This figure shows the same populations at time $=$ 2 (squares). The distances between populations are smaller and all squares are closer to the center of the plot (small gray arrows). This indicates that genetic integration increased among these populations through time, likely due to increased gene flow and migration among them. One can also compare variability within a population through time (large gray arrow). Patterns of within and between population variation as well as distances among samples are critical to evolutionary inferences

diversity observed by protohistoric chroniclers throughout the region (Deagan 1978; Jones 1978, 1980; Larson 1978; McEwan 2000; Milanich 1978, 2000; Saunders 2000; Worth 2002; see also Anderson 1994; Blitz 1999; Hally 2006).

2. Immediately after contact, during the early mission period, these same populations were less genetically integrated (Stojanowski 2005c, 2010). This is consistent with genetic drift working within local populations among which migration rates had declined. There appears to have been no change in long-range patterns of migration to counteract demographic collapse in the early years of missionization. In other words, the structure of interaction among populations had not changed but the intensity of interaction declined and was more localized.

3. The transition from the early to late mission period witnessed a dramatic reversal in the pattern of regional interaction and integration among distinct language communities (Fig. 3). Populations living throughout La Florida were highly biologically integrated during the period 1650-1700 (Stojanowski 2005c, 2010). This is surprising. Continuation of the processes active during the first half of the seventeenth century (\# 2 above) should lead to continued genetic divergence among those same populations. That the opposite was demon-

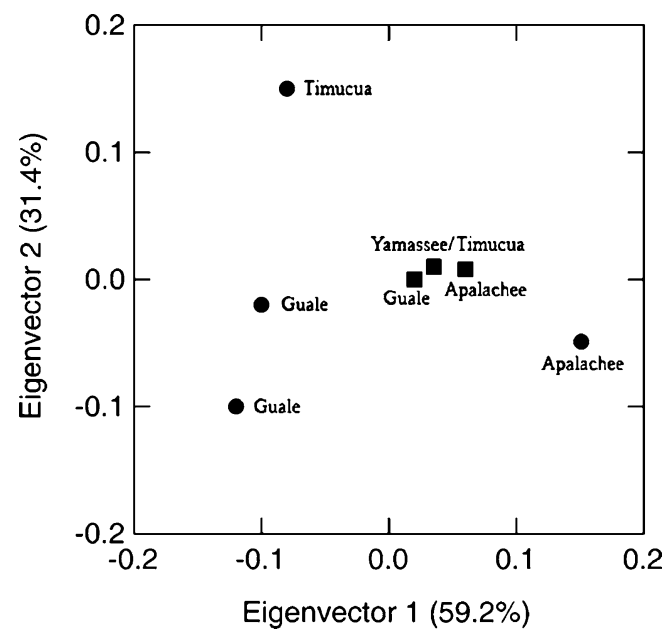

Fig. 3 Bivariate plot of multivariate output showing the relationships between early mission period (circles) and late mission period (squares) populations. Each sample represents a specific mission church cemetery. Labels indicate the ethnic or linguistic affiliation of that church. The patterning indicates continuity of populations through time within each province and much greater integration of populations among different provinces during the late mission period

strated suggests a major transition occurred in the structure of native populations. There is one explanation for this - migration and gene flow became much more widespread among converted native individuals living in the Spanish provinces during the latter half of the seventeenth century. Because the boundaries of the "population" had effectively expanded due to more widespread patterns of gene flow, the effects of genetic drift manifest regionally as a within-population effect (decreased variability).

4. Admixture with European and African individuals certainly occurred and was documented historically (Deagan 1983, 1985) but appears to have had little significant effect on patterns of indigenous variation. Admixed individuals (mestizos) were seemingly restricted to specific mission locations where burgeoning Hispanic communities were resident during the Spanish tenure in La Florida. Identity politics (sistema de castas) ensured a rigid social hierarchy based on parentage, and it is not surprising that such individuals would be buried in areas distinct from non-admixed indigenous individuals.

\section{Microevolution and Meaning}

While initially only interested in the evolutionary mechanisms responsible for the observed patterns of data (Stojanowski 2001), continued reflection on the meaning of these patterns led me to appreciate their relevance for 
understanding the social context in which the historic period changes occurred. Although it is easy to view these changes from a top-down European perspective (contact $=$ disease $=$ mortality $=$ population size decline $=$ aggregation), doing so ignores the active participation of the native populations and affords them no role in determining their later history. But the changes observed during the latter half of the seventeenth century clearly indicate action on the part of native communities. This is evidenced by the reversal of the trend documented through evolutionary analyses (from less integrated among mission populations to much more integrated among mission populations) in the face of continued declines in population size. If drift were the sole or primary determinant of genetic variability levels and patterns of community interrelationships, then the early mission period pattern of decreasing integration should have continued throughout the seventeenth century. But it did not continue. The pattern reversed and did so in a very stark way. The only interpretation of this signature is that gene flow rapidly expanded to homogenize the remaining indigenous peoples in La Florida. This only occurs through purposeful action.

Clearly then, the remaining Spanish faithful actively sought integration with their social peers-those who converted to Catholicism; those who were similarly discriminated against by other indigenous groups for being Catholic; those who increasingly made more similar types of pottery and the other trappings of life, ate similar types of maize-based diets, suffered poor health or lost loved ones to periodic epidemics, had relatives living as disaffected fugitives, and buried their dead in formal Christian cemeteries; and those who could never attain the social rank of continental or creole Spaniards. The social and historical context within which these evolutionary changes were occurring suggests the peoples of northern Florida and coastal Georgia were actively forging a new social identity. This is ethnogenesis. From multiple identities emerged a nascent, singular identity - that of a native Catholic Indian living under the Spanish flag. Existing social boundaries increasingly lost meaning during the seventeenth century through generational turnover (those newly born into Catholic communities knew less of the "old ways") and the highly charged, racialized social context of late seventeenth century La Florida (see Bushnell 2006). This identity was unnamed and unrecognized by ecclesiastical sources, secular bureaucrats, and the foreign visitors to the colony that were responsible for the recorded history that is so well known. When history fails to name something, it almost ceases to exist. In this case, a highly ephemeral human construct, a social identity, was nearly lost to history, barely resurrected through microevolutionary analysis of human skeletal data from seventeenth century church cemeteries.

\section{Seminole Ethnogenesis: How Evolution Bridges "Histories"}

The Catholic Indian population of Spanish Florida was developing a common shared identity during the latter half of the seventeenth century. This is reflected in patterns of material culture (quotidian behavior) and phenotypic variation (reproductive behavior). But these missions were all destroyed during the first decade of the eighteenth century; the populations living there were scattered, enslaved, or killed during the conflicts. A few hundred escaped to St. Augustine where they lived for several generations before disappearing from history. Or perhaps this is too simple a history. And if not too simple, then what is the relevance of this inferred ethnogenetic process for modern indigenous peoples of Florida?

To answer this, we must consider the Florida Seminole who, along with the Miccosukkee, are the only two federally recognized tribes in Florida today. Established history suggests the Florida Seminole are not originally from Florida. Early Seminole bands were disaffected Lower Creeks from Georgia who came to Florida during the early to mid-eighteenth century, eventually coalescing into a distinct social and political identity (the Seminole) toward the end of the eighteenth century (Covington 1993; Craig and Peebles 1974; Leitch Wright 1981, 1986; Sturtevant 1971; Weisman 1989). Few recognize any historical, social, or biological connection between the Seminole and the precontact and mission period populations of Florida - the Apalachee-, Guale-, and Timucua-speaking groups subjected to missionization. The Seminole appear comfortable with this mid eighteenth century origin.

But what of the period between about 1706 (when the missions were destroyed) and the mid-1700s when the Seminole began to coalesce into bands in north-central Florida? As it turns out, ethnogenesis among the Catholic Indian communities is directly relevant to bridging this historical gap. After the missions were destroyed, northcentral Florida was basically devoid of people, and this was a problem for the Spanish who needed a physical buffer between their remnant of a colony in St. Augustine and English and French colonies now established west and north. In fact, native peoples started trickling back into Florida within one or two decades of the missions' destruction (Cline 1974; Sattler 1987, 1996; Wickman 1999). These peoples happened to settle in the two locations which maintained the largest indigenous population sizes during the seventeenth century. They were ethnically linked to the Apalachee and Yamassee peoples, both present in large numbers in later Spanish colonial Florida (see Green et al. 2002; Hann 1988). There is suggestion that Catholicism remained important to them (Sattler 1987, 1996; Wickman 1999). Slowly, the population size increased. The initial settlers brought with 
them fugitives, relatives from the Creek heartland in central Georgia. These were likely the same peoples that had left the Spanish mission system throughout the seventeenth century (Hann 1996b; Worth 1998), those that had "disappeared" from history in the short term only to reappear under a new name given to them by the Spanish and English observersthe Siminioles. These people had forged a common identity during the preceding decades and, when the time was right, retuned to Florida, which was essentially a return to their homeland. The trickle would become a wave as more and more indigenous peoples discovered they were unhappy living amongst the Lower Creeks. As history tells, these villages coalesced into bands, and increasing social and political distance from their northern Creek neighbors eventually resulted in ethnogenesis once again. These are the people we now call Seminoles. But Seminole origins must be found in the rationale of the initial settlers to return to Florida during the 1710s and 1720s. I argue that these initial settlers were those same peoples who had been living in Spanish colonial Florida during the last decades of the seventeenth century. They were those people who had forged a common Catholic Indian identity with their neighbors and relatives that had fled the mission system's burdens - those fugitives, those cimarrones, those Seminoles.

\section{Conclusions}

The narrative tone used throughout this paper is purposeful. It reflects the ability of evolutionary analyses to contribute to the broader social sciences and humanities. Here, I have shown how microevolutionary analyses inform social identities research, particularly ethnogenesis. For geneticists working with modern native populations, these results may be vexing in their suggested degree of complexity of population history. Simple branching models are insufficient representations of the origins of the Seminole, which entailed two distinct phases-each protracted-of ethnogenetic separation and merger. This process was highly context-specific and cannot be extrapolated to other regions. In other words, model building and generalization may be too lofty a goal for understanding the complexities of human social formations. But this begs the question: what is the goal of evolutionary research? If the answer is historical and descriptive (what happened when, where did population $\mathrm{x}$ come from), then ethnogenetic research must commence within a well-defined historical framework. Did these kinds of massive population reorganizations also occur in the deep historical past, or were they something unique to the colonial period in North America? These are questions that have broad importance for our understanding of the past as revealed in analyses of modern genetic variation.
However, this paper also highlights the humanistic side of evolutionary research. While my work is also descriptive and historical, the implications of the work are relevant to contemporary understanding. That is, evolutionary analyses of population variation in La Florida help reconstruct a people's history that is only partially known through texts and material culture analyses. But evolutionary analyses reflect patterns of human behavior not often included in the pages of history or in the designs of potters. As a result, such analyses supplement the material history of the past in unique ways. In this case, the view of Seminole history and ethnogenesis presented here further legitimizes the Seminole as "Indians of Florida." The history is complex. It is rhizomic (see Moore 1994a, b, 2001)—branching and recombining many times from prehistory through European colonization, the emergence of the American nation, and then the American South. But this historical-evolutionary narrative has implications for the Seminole's view of themselves, as well as how the Seminole are viewed by others. So while it is descriptive and historical, this research also causes us to rethink our understanding of the world. For this reason, it is also humanistic.

\section{References}

Anderson DG. Factional competition and the political evolution of Mississippian chiefdoms in the Southeastern United States. In: Brumfiel E, Fox JW, editors. Factional competition and political development in the new world. New York: Cambridge University Press; 1994. p. 61-76.

Bennett CE. Laudonnière \& Fort Caroline. History and documents. Tuscaloosa: University of Alabama Press; 2001.

Blitz JH. Mississippian chiefdoms and the fission-fusion process. Am Antiq. 1999;64:577-92.

Bowne EE. The Westo Indians. Slave traders of the early Colonial South. Tuscaloosa: University of Alabama Press; 2005.

Boxer CF. Women in Iberian expansion overseas, 1415-1815. New York: Oxford University Press; 1975.

Boyd MF, Smith HG, Griffin JW. Here they once stood: the tragic end of the Apalachee missions. Gainesville: University of Florida Press; 1951.

Boyd R, Richerson PJ. The evolution of ethnic markers. Cult Anthropol. 1987;2:65-79.

Boyd R, Richerson PJ. Culture and the evolutionary process. Chicago: University of Chicago Press; 1985.

Bushnell AT. The sacramental imperative: Catholic ritual and Indian sedentism in the provinces of Florida. In: Thomas DH, editor. Columbian consequences vol. 2. Archaeological and Historical Perspectives on the Spanish Borderlands East. Washington, DC: Smithsonian Institution Press; 1990. p. 475-90.

Bushnell AT. Ruling "the Republic of Indians" in seventeenth-century Florida. In: Waselkov GA, Wood PH, Hatley MT, editors. Powhatan's mantle: Indians in the Colonial Southeast. Lincoln: University of Nebraska Press; 2006. p. 195-213.

Cline HF. Notes on Colonial Indians and communities in Florida 1700-1821. New York: Garland; 1974.

Covington JW. The seminoles of Florida. Gainesville: University Press of Florida; 1993. 
Craig AK, Peebles C. Ethnoecologic change among the seminoles, 1740-1840. Geosci Man. 1974;5:83-96.

Deagan KA. Mestizaje in Colonial St. Augustine. Ethnohist. 1973;20:53-65.

Deagan KA. Cultures in transition: Fusion and assimilation among the Eastern Timucua. In: Milanich J, Proctor S, editors. Tacachale: essays on the Indians of Florida and Southeastern Georgia during the historic period. Gainesville: University Presses of Florida; 1978. p. 89-119.

Deagan K. Spanish St. Augustine: the archaeology of a Colonial Creole community. New York: Academic; 1983.

Deagan KA. Spanish-Indian interaction in sixteenth century Florida and Hispaniola. In: Fitzhugh WW, editor. Cultures in contact. Washington, DC: Smithsonian Institution Press; 1985.

Dobyns HF. Estimating aboriginal American population 1: an appraisal of techniques with a new hemispheric estimate. Curr Anthropol. 1966;7:395-449.

Dobyns HF. Their number become thinned: Native American population dynamics in Eastern North America. Knoxville: University of Tennessee Press; 1983.

Dobyns HF. The invasion of Florida: disease and the Indians of Florida. In: Henderson AL, Mormino GR, editors. Spanish pathways in Florida: 1492-1992. Sarasota: Pineapple Press; 1991. p. $58-77$.

Durham WH. Co-evolution: genes, culture and human diversity. Stanford: Stanford University Press; 1991.

Ethrdige R. Creating the shatter zone: Indian slave traders and the collapse of the Southeastern Chiefdoms. In: Pluckhahn TJ, Ethridge R, editors. Light on the path. The anthropology and history of the Southeastern Indians. Tuscaloosa: University of Alabama Press; 2006. p. 207-18.

Ethridge R, Shuck-Hall SM. Mapping the Mississippian shatter zone: the Colonial Indian slave trade and regional instability in the American South. Lincoln: University of Nebraska Press; 2009.

Gannon MV. The cross in the sand: the early catholic church in Florida, 1513-1870. Gainesville: University Presses of Florida; 1983.

Geiger M. The Franciscan conquest of Florida (1573-1618). PhD dissertation, Catholic University of America; 1937.

Green W, DePratter CB, Southerlin B. The Yamassee in South Carolina: Native American adaptation and interaction along the Carolina Frontier. In: Joseph JW, Zierden M, editors. Another's country: archeological and historical perspectives on cultural interactions in the Southern Colonies. Tuscaloosa: University of Alabama Press; 2002. p. 13-29.

Hally DJ. The nature of Mississippian regional systems. In: Pluckhahn TJ, Ethridge R, editors. Light on the path. The anthropology and history of the Southeastern Indians. Tuscaloosa: University of Alabama Press; 2006. p. 26-42.

Hann JH. Demographic patterns and changes in mid-seventeenth century Timucua and Apalachee. F1 Hist Quart. 1986;64:371-92.

Hann JH. Twilight of the Mocamo and Guale Aborigines as portrayed in the 1695 Spanish visitation. F1 Hist Quart. 1987;66:1-24.

Hann JH. Apalachee: the land between the rivers. Gainesville: University Presses of Florida; 1988.

Hann JH. De Soto, Dobyns, and demography in Western Timucua. Fla Anthropol. 1990;43:3-12.

Hann JH. A history of the Timucua Indians and Missions. Gainesville: University Press of Florida; 1996a.

Hann JH. Late seventeenth-century forebears of the lower creeks and seminoles. Southeast Archaeol. 1996b;15:66-80.

Hill JD. Introduction: ethnogenesis in the Americas, 1492-1992. In: Hill JD, editor. History, power and identity. Ethnogenesis in the Americas, 1492-1992. Iowa City: University of Iowa Press; 1996. p. $1-19$.

Jones BC, Shapiro GN. Nine mission sites in Apalachee. In: Thomas DH, editor. Columbian consequences vol. 2: Archaeological and historical perspectives on the Spanish Borderlands East. Washington, DC: Smithsonian Institution Press; 1990. p. 491-510.

Jones GD. The ethnohistory of the Guale coast through 1684. In: Thomas DH, Jones GD, Durham RS, Larsen CS, editors. The anthropology of St. Catherines Island. 1. Natural and cultural history. Anthropological papers 55, pt 2. New York: American Museum of Natural History; 1978. p. 178-210.

Jones GD. Guale Indians of the Southeastern United States coast. In: Howard JD, DePratter CB, Frey RW, editors. Excursions in southeastern geology: the archaeology-geology of the Georgia Coast. Atlanta: The Geological Society of America; 1980. p. 215-24.

Kelton P. The great southeastern smallpox epidemic, 1696-1700: the region's first major epidemic? In: Ethridge R, Hudson C, editors. The transformation of the Southeastern Indians, 1540-1760. Jackson: University Press of Mississippi; 2002. p. 21-37.

Kelton P. Epidemics and enslavement: biological catastrophe in the Native Southeast 1492-1715. Lincoln: University of Nebraska Press; 2007.

Kieser JA. Human adult odontometrics: the study of variation in adult tooth size. New York: Cambridge University Press; 1990.

Laland KV, Odling-Smee J, Myles S. How culutre shaped the human genome: bringing genetics and the human sciences together. Nat Rev Genet. 2010;11:137-48.

Landers J. Africans in the Spanish Colonies. Hist Archaeol. 1997;31:84-91.

Lanning JT. The Spanish missions of Georgia. Chapel Hill: University of North Carolina Press; 1935.

Larsen CS. Bioarchaeology of La Florida: human biology in Northern Frontier New Spain. Gainesville: University Press of Florida; 2001.

Larsen CS, Crosby AW, Griffin MC, Hutchinson DL, Ruff CB, Russell KF, et al. A biohistory of health and behavior in the Georgia Bight: the agricultural transition and the impact of European contact. In: Steckel RH, Rose JC, editors. The backbone of history: health and nutrition in the Western Hemisphere. New York: Cambridge University Press; 2001. p. 406-39.

Larson LH. Historic Guale Indians of the Georgia Coast and the impact of the Spanish mission effort. In: Milanich JT, Proctor S, editors. Tacachale: essays on the Indians of Florida and Southeastern Georgia during the historic period. Gainesville: University Presses of Florida; 1978. p. 120-40.

Leitch Wright J. The only land they knew. New York: The Free Press; 1981.

Leitch Wright J. Creeks and seminoles. Lincoln: University of Nebraska Press; 1986.

Lyon E. The enterprise of Florida. In: Thomas DH, editor. Columbian consequences, vol 2: Archaeological and historical perspectives on the Spanish borderlands east. Washington, DC: Smithsonian Institution Press; 1990. p. 281-96.

MacElreath R, Boyd R, Richerson PJ. Shared norms and the evolution of ethnic markers. Curr Anthropol. 2003;44:122-9.

McEwan BG. The archaeology of women in the Spanish New World. Hist Archaeol. 1991;25:33-41.

McEwan BG. The Spanish missions of La Florida. Gainesville: University Press of Florida; 1993.

McEwan BG. The Apalachee Indians of Northwest Florida. In: McEwan BG, editor. Indians of the greater southeast. Gainesville: University Press of Florida; 2000. p. 57-84.

McEwan BG. The spiritual conquest of Florida. Am Anthropol. 2001;103:633-44.

Milanich JT. The Western Timucua: patterns of acculturation and change. In: Milanich JT, Proctor S, editors. Tacachale: essays on the Indians of Florida and Southeastern Georgia during the historic period. Gainesville: University Presses of Florida; 1978. p. $59-88$. 
Milanich JT. The Timucua. Cambridge: Blackwell; 1996.

Milanich JT. Laboring in the fields of the Lord. Washington, DC: Smithsonian Institution Press; 1999.

Milanich JT. The Timucua Indians of Northern Florida and Southern Georgia. In: McEwan BG, editor. Indians of the Greater Southeast. Gainesville: University Press of Florida; 2000. p. 125.

Milanich JT. Timucua. In: Fogelson RD, editor. Handbook of North American Indians. Washington, DC: Southeast, Smithsonian Institution Press; 2004. p. 219-28.

Moore JH. Ethnogenetic theory. Natl Geogr Res Explor. 1994a;10:10 23.

Moore JH. Putting anthropology back together again: the ethnogenetic critique of cladistic theory. Am Anthropol. 1994b;96:925-48.

Moore JH. Ethnogenetic patterns in Native North America. In: Terrell JE, editor. Archaeology, language, and history: essays on culture and ethnicity. Westport, Conn: Bergin and Garvey; 2001. p. 3156.

Nielsen R, Hellmann I, Hubisz M, Bustamante C, Clark AG. Recent and ongoing selection in the human genome. Nat Rev Genet. 2007;8:857-68.

Oré LG. The martyrs of Florida. New York: Wagner; 1936.

Relethford $\mathrm{JH}$. Anthropometric data and population history. In: Herring DA, Swedlund AC, editors. Human biologists in the archives: demography, health, nutrition, and genetics in historical populations. Cambridge: Cambridge University Press; 2003. p. $32-52$.

Relethford JH, Crawford MH, Blangero J. Genetic drift and gene-flow in post-famine Ireland. Hum Biol. 1997;69:443-65.

Rendell L, Fogarty L, Laland KN. Runaway cultural niche construction. Phil Trans R Soc B. 2011;366:823-35.

Richerson PJ, Boyd R. Not by genes alone: how culture transformed human evolution. Chicago: University of Chicago Press; 2005.

Richerson PJ, Boyd R, Henrich J. Gene-culture coevolution in the age of genomics. Proc Nat Acad Sci USA. 2010;107(2):898592.

Sabeti PC et al. Positive natural selection in the human lineage. Science. 2006;312:1614-20.

Sabeti PC et al. Genome-wide detection and characterization of positive selection in human population. Nature. 2007;449:913-8.

Salter F. A defense and an extension of Pierre van den Berghe's theory of ethnic nepotism. In: James P, Goetze D, editors. Evolutionary theory and ethnic conflict. Wesport: Greenwood; 2001. p. 39-70.

Salter F. Welfare, ethnicity, and altruism: new data and evolutionary theory. London: Frank Cass; 2004.

Sattler RA. Seminoli italwa: socio-political change among the Oklahoma seminoles between removal and allotment, 18361905. PhD dissertation, University of Oklahoma; 1987.

Sattler RA. Remnants, renegades, and runaways: seminole ethnogenesis reconsidered. In: Hill JD, editor. History, power and identity. Ethnogenesis in the Americas, 1492-1992. Iowa City: University of Iowa Press; 1996. p. 36-69.

Saunders R. The Guale Indians of the lower Atlantic coast: change and continuity. In: McEwan BG, editor. Indians of the greater Southeast. Gainesville: University Press of Florida; 2000. p. 26-56.

Spellman CW. The "golden age" of the Florida mission, 1632-1674. Cathol Hist Rev. 1965;51:355-78.

Stojanowski CM. Cemetery structure, population aggregation and biological variability in the mission centers of La Florida. PhD dissertation, University of New Mexico; 2001.

Stojanowski CM. Matrix decomposition model for investigating prehistoric intracemetery biological variation. Am J Phys Anthropol. 2003a;122:216-31.
Stojanowski CM. Differential phenotypic variability among the Apalachee populations of La Florida: a diachronic perspective. Am J Phys Anthropol. 2003b;120:352-63.

Stojanowski CM. Population history of native groups in pre- and postcontact Spanish Florida: aggregation, gene flow, and genetic drift on the Southeastern U.S. Atlantic Coast. Am J Phys Anthropol. 2004;123:316-22.

Stojanowski CM. Biological structure of the San Pedro y San Pablo de Patale mission cemetery. Southeast Archaeol. 2005a;24:165-79.

Stojanowski CM. Spanish colonial effects on Native American mating structure and genetic variability in Northern and Central Florida: evidence from Apalachee and Western Timucua. Am J Phys Anthropol. 2005b;128:273-86.

Stojanowski CM. The bioarchaeology of identity in Spanish Colonial Florida: social and evolutionary transformation before, during, and after demographic collapse. Am Anthropol. 2005c;107:417-31.

Stojanowski CM. Biocultural histories of La Florida: a bioarcheological perspective. Tuscaloosa: University of Alabama Press; 2005d.

Stojanowski CM. Bridging histories: the bioarchaeology of identity in postcontact Florida. In: Knudson KJ, Stojanowski CM, editors. Bioarchaeology of identity in the Americas. Gainesville: University Press of Florida; 2009. p. 59-81.

Stojanowski CM. Bioarchaeology of ethnogenesis in the colonial Southeast. Gainesville: University Press of Florida; 2010.

Sturtevant W. Creek into Seminole. In: Leacock E, Lurie N, editors. North American Indians in historical perspective. New York: Random House; 1971. p. 92-128.

Thomas DH. The Spanish missions of La Florida: an overview. In: Thomas DH, editor. Columbian consequences: vol 2, Archaeological and historical perspectives on the Spanish Borderlands East. Washington, DC: Smithsonian Institution Press; 1990. p. 357-98.

Van den Berghe PL. The ethnic phenomenon. New York: Elsevier; 1981.

Varki A, Geschwind DH, Eichler EE. Explaining human uniqueness: genome interactions with environment, behaviour and culture. Nat Rev Genet. 2008;9:749-63.

Weisman BR. Like beads on a string. A culture history of the seminole Indians in Northern Peninsular Florida. Tuscaloosa: University of Alabama Press; 1989.

Wickman PR. The tree that bends: discourse. Power and the survival of the Maskókî peoples. Tuscaloosa: University of Alabama Press; 1999

Worth JE. The struggle for the Georgia Coast: an eighteenth-century Spanish retrospective on Guale and Mocama. American Museum of Natural History, Anthropological papers, no. 75; 1995.

Worth JE. The Timucuan chiefdoms of Spanish Florida vol 2: resistance and destruction. Gainesville: University Press of Florida; 1998

Worth JE. The ethnohistorical context of bioarchaeology in Spanish Florida. In: Larsen CS, editor. Bioarchaeology of Spanish Florida: the impact of colonialism. Gainesville: University Press of Florida; 2001. p. 1-21.

Worth JE. Spanish missions and the persistence of chiefly power. In: Ethridge R, Hudson C, editors. The transformation of the Southeastern Indians, 1540-1760. Jackson: University Press of Mississippi; 2002. p. 39-64.

Worth JE. Guale. In: Fogelson RD, editor. Handbook of North American Indians: Southeast. Washington, DC: Smithsonian Institution Press; 2004. p. 238-44.

Worth JE. Bridging prehistory and history in the Southeast: evaluating the utility of the acculturation concept. In: Pluckhahn TJ, Ethridge R, editors. Light on the path. The anthropology and history of the Southeastern Indians. Tuscaloosa: University of Alabama Press; 2006. p. 196-206. 